\title{
A Cognitive Study of Metaphors in the Glorious Qur'an: From a Linguistic to a Conceptual Approach
}

\author{
Mashael AlAjmi \\ Department of Applied Linguistics, Faculty of Languages \\ Princess Nourah bint Abdulrahman University \\ Riyadh, Saudi Arabia
}

\begin{abstract}
The current study investigates the use of conceptual metaphors in the glorious Qur'an, focusing on four abstract concepts represented in the Qur'an through metaphors. These concepts are REWARD, HUMILITY, HYPOCRISY, and ARROGANCE, which recur in many positions in the Qur'an. The researcher takes up selected Qur'anic verses that carry these abstract concepts and analyzes them at two levels: linguistic and conceptual. The study's main theoretical contribution is to show how a linguistic approach can be transformed into a conceptual one and how this enriches our understanding of abstraction. The linguistic analysis of the verses is supported by translations of Qur'anic meanings, interpretation of the verses, and cultivating the use of Arabic and English dictionaries. To perform the cognitive analysis, the researcher uses Lakoff and Johnson's Conceptual Metaphor Theory (CMT), which examines metaphor from two domains: the target domain, which is the abstract concept to be explained and the source domain, which is the mental mapping that helps us understand that abstract concept. The study finds that metaphors in the Qur'an are meant to be understood not only linguistically but conceptually too. It concludes by emphasizing the significance of a conceptual approach to the study of metaphor in the Qur'an not only for conceptual metaphor theory but also for the interpretation of the Qur'an and for Arabic linguistics.

Keywords: abstract concept, cognitive, linguistic metaphor, conceptual metaphor, Qur'an, source domain, target domain
\end{abstract}

Cites as: AlAjmi, M. (2019). A Cognitive Study of Metaphors in the Glorious Qur'an: From a Linguistic to a Conceptual Approach. Arab World English Journal for Translation \& Literary Studies, 3 (2). 114-121. DOI: http://dx.doi.org/10.24093/awejtls/vol3no2.10 